\title{
Erratum to: Influence of arbuscular mycorrhizal fungi and copper on growth, accumulation of osmolyte, mineral nutrition and antioxidant enzyme activity of pepper (Capsicum annuum L.)
}

\author{
Arafat Abdel Hamed Abdel Latef
}

Published online: 16 September 2011

(C) Springer-Verlag 2011

\section{Erratum to: Mycorrhiza}

DOI 10.1007/s00572-010-0360-0

The Editors-in-Chief of "Mycorrhiza" in agreement with the publisher hereby retracts the article entitled "Influence of arbuscular mycorrhizal fungi and copper on growth, accumulation of osmolyte, mineral nutrition and antioxidant enzyme activity of pepper (Capsicum annuum L.)" by Arafat Abdel Hamed Abdel Latef; published online in "Mycorrhiza" on January 8, 2011.

This article has been retracted due to copyright issues that cannot be resolved. 10.1007/s00572-010-0360-0.

A. A. H. Abdel Latef $(\bowtie)$

Department of Botany, Faculty of Science,

South Valley University,

83523 Qena, Egypt

e-mail: moawad76@gmail.com 